\section{AUTHORS:}

Isabel M. Hulley ${ }^{1}$

Patricia M. Tilney

Sandy F. Van Vuuren² iD

Guy P.P. Kamatou ${ }^{3}$ iD

Janneke M. Nortje

Alvaro M. Viljoen ${ }^{3}$

Ben-Erik Van Wyk

\section{AFFILIATIONS:}

'Department of Botany and Plant Biotechnology, University of Johannesburg, Johannesburg, South Africa

2Department of Pharmacy and Pharmacology, University of the Witwatersrand, Johannesburg, South Africa

${ }^{3}$ Department of Pharmaceutical Sciences, Tshwane University of Technology, Pretoria,

South Africa

\section{CORRESPONDENCE TO:}

Ben-Erik Van Wyk

EMAIL:

bevanwyk@uj.ac.za

\section{DATES:}

Received: 04 Feb. 2016

Revised: 05 May 2016

Accepted: 06 May 2016

\section{KEYWORDS:}

Asteraceae; essential oil; ethnobotany; leaf anatomy; antimicrobial activity

\section{HOW TO CITE:}

Hulley IM, Tilney PM, Van Vuuren SF, Kamatou GPP, Nortje JM, Viljoen AM, et al. San and Nama indigenous knowledge: The case of Inhora (Pteronia camphorata) and its medicinal use. S Afr J Sci. 2016:112(9/10), Art. \#2016-0044, 9 pages http://dx.doi.org/10.17159/ sajs.2016/20160044

\section{ARTICLE INCLUDES:}

$\times$ Supplementary material

$\times$ Data set

\section{FUNDING:}

National Research Foundation (South Africa)

\section{(c) 2016. The Author(s).} Published under a Creative Commons Attribution Licence.

\title{
San and Nama indigenous knowledge: The case of |nhora (Pteronia camphorata) and its medicinal use
}

\begin{abstract}
A hitherto unidentified medicinal plant is here identified for the first time as Pteronia camphorata (L.) L., an aromatic shrub of the Asteraceae family endemic to the western and southern coastal region of South Africa. The plant was described in this journal by Laidler' in 1928 as 'D/nhora buchu', and is one of the important types of buchu used by the Nama people. We report the traditional medicinal uses among San and Nama people, based on our interviews with rural participants. These include the treatment of colds, influenza, chest ailments and tuberculosis, as well as convulsions, haemorrhoids and inflammation of the neck. The major and minor chemical compounds of the essential oil that is produced by the plant are identified, together with the site of accumulation of this volatile oil within the leaf. We also investigated the plant's antimicrobial activity against a selection of a yeast and two Gram-negative and one Gram-positive bacteria, all of which are associated with respiratory infections. $P$. camphorata is scientifically poorly known but is an important San and Nama traditional remedy. Our study not only prevents the potential loss of historically important indigenous knowledge, but also provides the first scientific evidence to validate the traditional use of |nhora against upper and lower respiratory tract infections, including tuberculosis. This detailed study has wider application in demonstrating the fragility of the oral-traditional knowledge of a scientifically neglected indigenous group. It also highlights the scientific and practical importance of preserving traditional plant-use knowledge within a botanically diverse region.
\end{abstract}

\section{Significance:}

- Reveals the botanical identity of |nhora, an important Nama medicinal plant.

- Presents scientific evidence to validate the traditional uses.

- Contributes to the cultural heritage of a scientifically neglected indigenous group.

- Demonstrates the fragility of oral-traditional knowledge.

\section{Introduction}

The traditional Khoi and San practices of plant use in the botanically rich Cape region of South Africa are poorly documented. They are also rapidly diminishing because of the fragility of orally transferred indigenous knowledge, and the fact that modern medicine has almost completely replaced the traditional health care system. Because the Khoi and San peoples are ancestral to the rest of humanity, their ethnobotanical knowledge is of global significance. It provides insights into the early history and origins of medicinal plant use. We therefore hope to prevent the loss of profound ethnobotanical information relating to an important fynbos-endemic medicinal plant. Fynbos is a natural shrubland or heathland vegetation located in the south-western part of South Africa.

The hitherto unidentified plant described by Laidler' in 1928 as 'D/nhora', one of the important types of buchu used by the Nama people, is here identified for the first time as Pteronia camphorata (L.) L. (Asteraceae). 'Buchu' (boegoe) refers to aromatic plants that are used, often in powdered form, for medicinal and cosmetic purposes. Laidler used $D$ / to denote the voiceless (tenuis) dental click, but we use the pipe symbol (|) in accordance with the International Phonetic Alphabet. Some linguists still prefer the (t) symbol of the Doke / Beach convention.

The cultural and historical importance of this species came to light gradually, mainly because of ethnobotanical field survey work in Namaqualand. ${ }^{2}$ Only ten elderly persons, two of whom are now deceased, had traditional knowledge about $P$. camphorata and its use in San and Nama medicine. Pteronia L. is a genus of roughly 70 small shrubs subendemic to southern Africa $^{3}$ and has been the focus of recent ethnobotanical studies ${ }^{4-6}$. Although these aromatic plants are of considerable local importance as sources of traditional medicine, their ethnobotany, leaf anatomy, essential oil chemistry and antimicrobial activity had previously not been studied systematically. $P$. camphorata is a small shrub of up to $0.8 \mathrm{~m}$ in height; it has a wide distribution in the Northern, Western and Eastern Cape provinces of South Africa. Four varieties have been distinguished (Figure 1), based on leaf arrangement (alternate or opposite) and the presence and density of white hairs (cilia) on leaf surfaces and margins. ${ }^{3}$

We wish to dispel the myth that indigenous knowledge is mainly of cultural and symbolic value, with limited practical use in health care. Our study explores the scientific rationale for the main use of |nhora in treating respiratory infections, including tuberculosis. For this purpose we conducted a detailed scientific study of the ethnobotany, leaf anatomy, essential oil chemistry and antimicrobial activity of $P$. camphorata.

\section{Materials and methods}

\section{Materials studied}

Three fresh samples of $P$. camphorata var. armata were collected at Kleinvlei, close to Wupperthal $\left(32^{\circ} \mathrm{S}, 19^{\circ} \mathrm{E}\right)$, for the purpose of essential oil analysis and antimicrobial studies. Samples of all four varieties of $P$. camphorata were collected at various localities for anatomical study. Exact localities, voucher specimen details and authorities for names are shown in Table 1. 


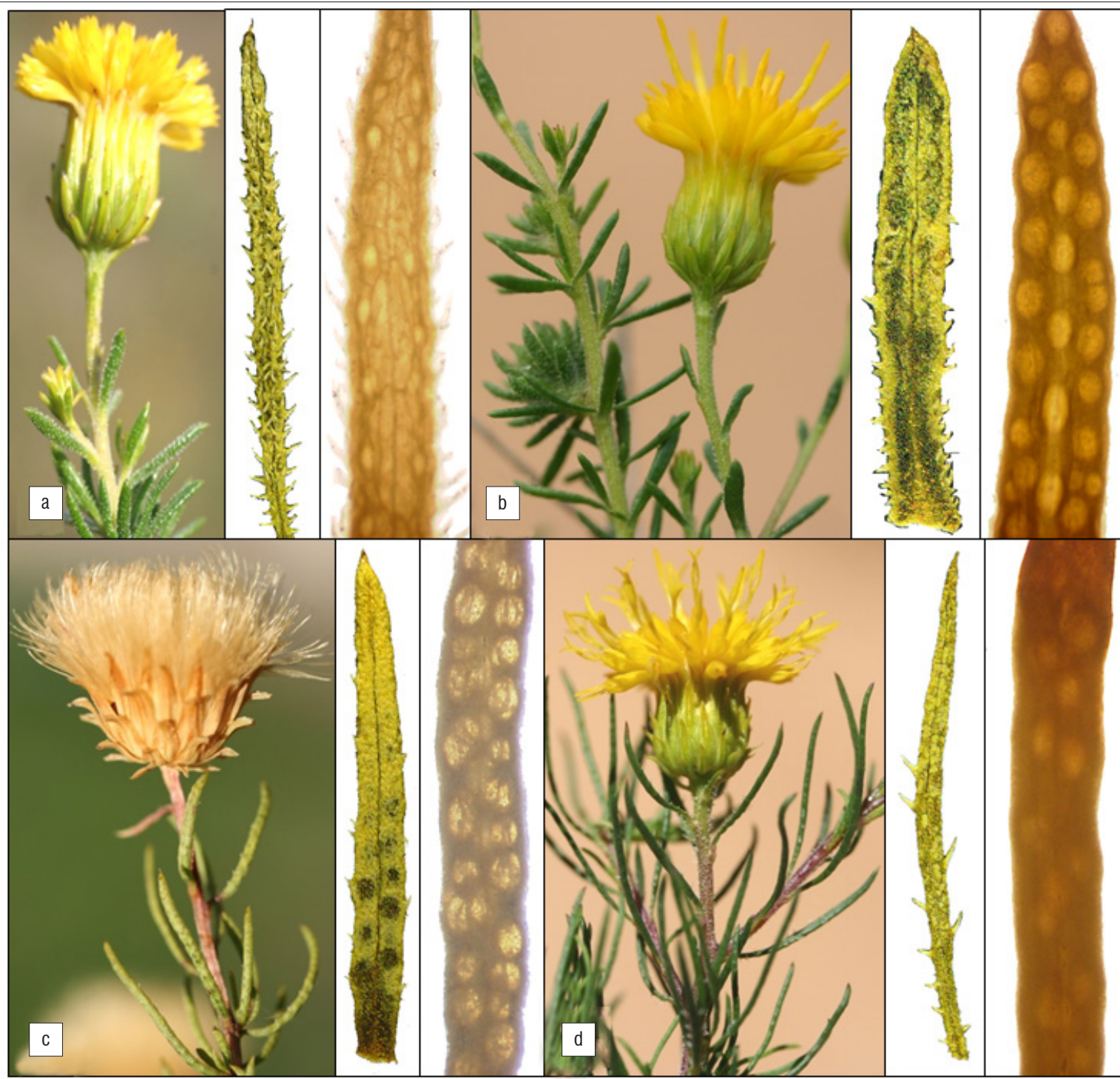

Figure 1: The morphology of flower-heads and leaves of four varieties of Pteronia camphorata. Specimens were (a) P. camphorata var. armata at Kleinvlei near Wupperthal, (b) P. camphorata var. camphorata at Dasklip Pass near Porterville, (c) P. camphorata var. laevigata at Nieuwoudtville, and (d) P. camphorata var. Iongifolia from Paarl Mountain. Note the distribution of cilia on leaves and presence of translucent oil glands. Photographs by B.E. Van Wyk.

Table 1: $\quad$ Voucher specimen details of the plant materials of Pteronia camphorata that were studied

\begin{tabular}{|c|c|c|c|c|}
\hline Variety & Locality & Date collected & $\begin{array}{l}\text { Voucher specimens } \\
\text { (all housed in JRAU) }\end{array}$ & $\begin{array}{l}\text { Anatomy (A) } \\
\text { Extracts for antimicrobial (MIC) } \\
\text { and chemical composition } \\
\text { (GC-MS) }\end{array}$ \\
\hline $\begin{array}{l}\text { P. camphorata (L.) L. var. armata } \\
\text { Harv. }\end{array}$ & Kleinvlei, Wupperthal & 4 October 2009 & $\begin{array}{l}\text { B.-E. Van Wyk, I.M. Hulley \& P.M. } \\
\text { Tilney } 4443\end{array}$ & MIC, GC-MS, A \\
\hline $\begin{array}{l}\text { P. camphorata (L.) L. var. } \\
\text { camphorata }\end{array}$ & Dasklip Pass, Porterville & 3 October 2009 & $\begin{array}{l}\text { B.-E. Van Wyk, I.M. Hulley \& P.M. } \\
\text { Tilney } 4428\end{array}$ & A \\
\hline $\begin{array}{l}\text { P. camphorata (L.) L. var. laevigata } \\
\text { Harv. }\end{array}$ & Nieuwoudtville, Oorlogskloof & 19 August 1997 & B.-E. Van Wyk 3702 & A \\
\hline $\begin{array}{l}\text { P. camphorata (L.) L. var. laevigata } \\
\text { Harv. }\end{array}$ & $\begin{array}{l}\text { Nieuwoudtville, } \\
\text { Oorlogskloof }\end{array}$ & 11 December 2008 & B.-E. \& M. Van Wyk 4287 & A \\
\hline $\begin{array}{l}\text { P. camphorata (L.) L. var. Iongifolia } \\
\text { Harv. }\end{array}$ & Paarl Mountain & 3 October 2009 & $\begin{array}{l}\text { B.-E. Van Wyk, I.M. Hulley \& P.M. } \\
\text { Tilney } 4427\end{array}$ & A \\
\hline
\end{tabular}




\section{Ethnobotanical interviews}

The recording of ethnobotanical data strictly adhered to all the ethical principles in the Code of Ethics ${ }^{7}$ of the International Society of Ethnobiology. These include the concepts of traditional resource rights, educated prior informed consent, and respect for the privacy and customs of rural people. Formal approval was also obtained (by B.E.V.W. and J.M.N.) from the ethics committee of the Faculty of Science at the University of Johannesburg. The data presented here form part of two extensive ethnobotanical surveys in Namaqualand and the Cederberg region. The ethical clearance reference numbers are UJ Protocol No. 13 January 2015 (B.E.V.W., Cederberg survey and other studies); UJ Protocol No. 20 May 2011 (J.M.N., Kamiesberg survey, for MSc) and UJ Protocol No. 7 July 2015 (J.M.N., Namaqualand survey, for PhD).

Interviews were conducted in the local language, Afrikaans, and we used the matrix method as previously described ${ }^{2}$. An extensive network of local participants was interviewed: close to 100 people in Namaqualand and more than 30 people in the Cederberg region, including several local experts (Table 2). Our paper provides a firm starting date and geographical localities for the traditional knowledge associated with $P$. camphorata, including the identities of the knowledge holders.

\section{Anatomical procedures}

Dried leaf material of $P$. camphorata var. armata was rehydrated and placed in formaldehyde-acetic acid-alcohol (formaldehyde [40\%] : glacial acetic acid : ethanol [96\%] : distilled water, 2:1:10:7) together with fresh leaf material from the remaining three varieties, for $24 \mathrm{~h}$. Thereafter the material was treated according to the methods described previously ${ }^{4-6}$ (dehydration, infiltration with and embedding in glycol methacrylate, sectioning, staining and data capturing). Unstained slides were viewed under a polarising microscope to observe whether any crystals were present.

\section{Distillation and analysis of essential oil}

Leaves and twigs (roughly $300 \mathrm{~g}$ dry weight) from three different plants of $P$. camphorata var. armata (Table 3) were air-dried for 9 days, then subjected to hydro-distillation for 180 min using a Clevenger-type apparatus. The oils were weighed and stored in sealed vials in the dark at $4{ }^{\circ} \mathrm{C}$ before analysis.

The oils ( $20 \%$ diluted in hexane) were analysed by a gas chromatographymass spectrometry system using standardised settings, as described previously ${ }^{4}$. Compounds were identified by their mass spectral data and retention indices, as well as library searches of the NIST ${ }^{\circledR}$, Mass Finder ${ }^{\circledR}$ and Flavour ${ }^{\circledR}$ libraries.

\section{Antimicrobial studies}

Various extracts (Table 4) and the oil samples listed in Table 3 were investigated for antimicrobial activities, using the minimum inhibitory concentration (MIC) microtitre plate method as previously described 4 . A yeast (Cryptococcus neoformans, American type culture collection [ATCC] 90112) as well as two Gram-negative bacteria (Moraxella catarrhalis ATCC 23246 and Klebsiella pneumoniae ATCC 13883) and one Gram-positive bacterium (Mycobacterium smegmatis ATCC 14468) were selected for the study. All cultures were selected on the basis of their respiratory pathogenesis, with the exception of $M$. smegmatis, which is a non-pathogenic Mycobacterium strain with a faster growth rate than that of $M$. tuberculosis - hence its ease of use. Cryptococcus neoformans is associated with lung infection, and $M$. catarrhalis is known to cause bronchitis, sinusitis and laryngitis. Klebsiella pneumoniae commonly causes pneumonia. The preparation of bacterial cultures and the methodology followed, including the preparation of extracts, were exactly the same as described previously. ${ }^{4-6}$ MIC assays were undertaken in duplicate or triplicate on separate occasions, and the mean results are presented.

\section{Results and discussion}

\section{Ethnobotany}

A historically important ethnobotanical paper by Laidler ${ }^{1}$, published in this journal in 1928, gave the names of several species of buchu used in Namaqualand. The use of buchu (powdered aromatic bushes, usually stored in tortoise shells) as a topical treatment of the skin is of San origin, and is well described in the literature. ${ }^{4,8}$ Buchu, sab or $P / n k a o u$ (Laidler used $P /$ to denote the palatal or palato-alveolar click, $\neq$ ) is said to have two varieties. The first is $D /$ nhora (Inhora), $D /$ khonsa (|khonsa) or haas buchu, and the other is $P /$ kabourie ( $\neq$ kabourie). The botanical identities of these two plants have remained unknown, perhaps because Laidler was not a botanist or he saw only the powdered plant material. He described the use of the two buchu types as follows:

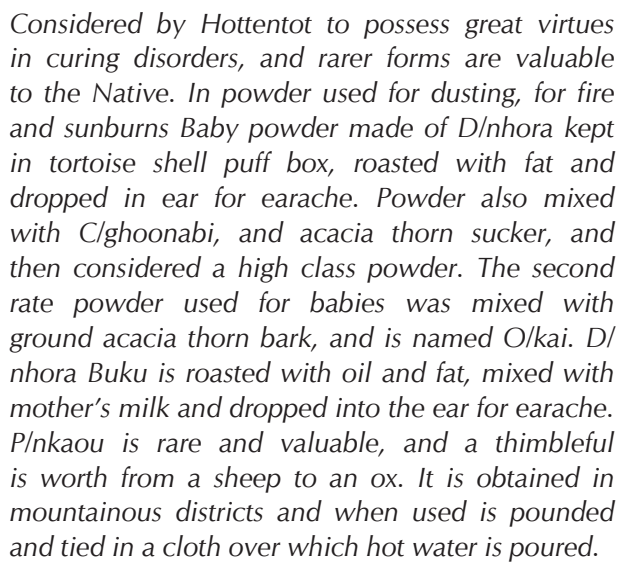

According to Laidler', the name $P / n k a o u$ was given to him for what was known as 'Buchu barosma' or 'Letulina' at the time. This clearly refers to round-leaf buchu, Agathosma betulina (P.J. Bergius) Pillans, a species confined to the mountainous region of the Bokkeveld, Cederberg and Grootwinterhoek. It is understandable that this plant would be considered rare and valuable, because it was not available locally but had to be transported over a considerable distance from the Cederberg to Namaqualand; the Kamiesberg is roughly $300 \mathrm{~km}$ north of the Cederberg. P/kabourie ( $¥$ kabourie) is not mentioned again, and the reader is left with the impression that this name also refers to P/nkaou.

The identification of $D /$ nhora (|nhora) as $P$. camphorata is the result of a few anecdotes spread over more than a decade. The first and most convincing was the explicit information given by Mr Willem 'Blikkies' Steenkamp at Nieuwoudtville, an area where the Namaqualand variety of the species (var. armata) also occurs naturally. All available ethnobotanical information on $P$. camphorata is shown in Table 2. Original anecdotes, recorded in Afrikaans, have been retained to ensure that subtle nuances about the plant and its uses are not lost in translation. P. camphorata shares with several other species the Afrikaans name gombossie. ${ }^{9-11}$

The first reference to $P$. camphorata as a medicinal plant appears on a herbarium specimen (E.B. Watermeyer 6350 in PRE). According to the label information, the specimen was collected in January 1925 and the plant is known as koortsbos (meaning koorsbos, i.e. fever bush). Unfortunately, the locality is given imprecisely as 'Little Namaqualand'. The first-ever published ethnobotanical use for $P$. camphorata, namely the treatment of boils, was reported by Watt and Breyer-Brandwijk' ${ }^{12}$, who cite $\mathrm{Kling}^{13}$ as the source of their information. Curiously, the species was not included in Rev. Kling's ${ }^{13}$ booklet of 1923 , so the origin of the information remains a mystery and appears to be based on a misinterpretation - uncritically cited by Arnold et al. ${ }^{14}$

The only other published ethnobotanical anecdote for the species was reported by Van Wyk and Gericke ${ }^{15}$, who cited Willem 'Blikkies' Steenkamp, an elderly man of Khoisan descent from the farm Oorlogskloof near Nieuwoudtville in the Northern Cape province of South Africa. The origin of the knowledge is Mr Steenkamp's grandfather, who was ethnically pure San. The plant is regarded as the most important of all the traditional medicines in the area, and is known locally as norraboegoe. 
Table 2: $\quad$ Summary of vernacular names and ethnobotanical anecdotes for Pteronia camphorata

\begin{tabular}{|c|c|}
\hline Vernacular names & Anecdotes and their origin \\
\hline $\begin{array}{l}\text { koortsbos: Herbarium specimen label } \\
\text { (January 1925, E.B. Watermeyer } 6350 \text { [PRE]) }\end{array}$ & - \\
\hline- & $\begin{array}{l}\text { Watt and Breyer-Brandwijk, } 1962^{12} \text { : 'A plaster, made from P. camphorata L., is used in the Western Cape for drawing } \\
\text { boils'. This is an error and cites Kling, } 1923^{13} \text { as the source. }\end{array}$ \\
\hline gombossie: Marloth, 19329; Smith, $1966^{10}$ & - \\
\hline $\begin{array}{l}\text { gombos, ghombossie: Burman and Bean, } \\
1985^{11}\end{array}$ & - \\
\hline $\begin{array}{l}\text { norraboegoe: Van Wyk and Gericke, } 2000^{15} \text {, } \\
\text { citing Willem 'Blikkies' Steenkamp }\end{array}$ & $\begin{array}{l}\text { 'Getrek in kookwater vir verkoue en griep; vir grootmense, gebruik soos dit is (baie bitter); vir kinders, gooi suiker by } \\
\text { en kook tot dit stroperig is.' [Infused in boiling water for colds and influenza; for adults, use as is (very bitter); for } \\
\text { children, add sugar and boil until syrupy.] }\end{array}$ \\
\hline $\begin{array}{l}\text { t/gôrroboegoe: Anna Brand } \\
\text { (Nourivier, Kamiesberg) }\end{array}$ & - \\
\hline $\begin{array}{l}\text { t/ôrro: Elizabeth Kardinaal } \\
\text { (Leliefontein, Kamiesberg) }\end{array}$ & $\begin{array}{l}\text { 'Hy is 'n boegoe, gebruik vir kinders met steek in die oor saam met moedersmelk, gooi in die oor en maak toe met 'n } \\
\text { pluisie (watte); word gemeng met melk ook vir grootmense met steek in die oor.' [lt is a buchu, used as medicine } \\
\text { for earache for infants, mixed with mother's milk as ear drops (cover with cotton wool); mixed with milk and used by } \\
\text { adults to treat ear infection.] }\end{array}$ \\
\hline $\begin{array}{l}\text { koorsbos: Gertruida Brand } \\
\text { (Paulshoek, Kamiesberg) }\end{array}$ & 'Trek hom af vir rumatiek.' [An infusion used for rheumatism.] \\
\hline $\begin{array}{l}\text { t/ôrroboegoe: Jakobus Brand } \\
\text { (Nourivier, Kamiesberg) }\end{array}$ & 'As poeier gebruik vir kinders se steek in die oor.' [Used as powder for earache in children.] \\
\hline $\begin{array}{l}\text { t/ôrro: Jan van der Westhuizen } \\
\text { (Garies, originally from Paulshoek but also } \\
\text { lived in Leliefontein) }\end{array}$ & $\begin{array}{l}\text { 'Die blaar word poeier gemaak en dan tee, dit is bitter, en gebruik vir winde.' [Powdered leaf used as bitter infusion for } \\
\text { flatulence.] }\end{array}$ \\
\hline $\begin{array}{l}\text { t/ôrro: Pieter Dirkse } \\
\text { (Paulshoek, Kamiesberg) }\end{array}$ & - \\
\hline $\begin{array}{l}\text { wakkerbos: Sors Cloete } \\
\text { (Paulshoek, Kamiesberg) }\end{array}$ & - \\
\hline
\end{tabular}

(1) 'Die plant het smal blaartjies. Gebruik as medisyne, snuif, saam met ander kruie; vir tandpyn (trek die takkie in melk of water); vir steek in die oor (vat die droë blare en maak ' $n$ poeier wat op watte in die oor gesit word) - dit het 'n pyndodende effek; trek ook daai wind uit.' [The plant has narrow leaves. Use as medicine, snuff, with other herbs; for toothache (steep a twig in milk or water); for pain in the ear (take the dry leaves and make a powder that is placed on cotton wool in the ear) - it has an analgesic effect; it also 'pulls out that wind' (relieves flatulence).]

t/nouroeboegoe, t/nôrraboegoe, t/nôrro: Anna Stewe (Leliefontein, Kamiesberg)

t/nôrro, t/nôrra, t/gôrrôboegoe: Gert Dirkse (Paulshoek, Kamiesberg)

t’ôrrôboegoe or t’ôrrôbosboegoe: Sarah Fortuin (Spoegrivier, Namaqualand)

(2) 'Org word gebruik vir TB. Dit word saam met jantjie-bêrend en t/nouroeboegoe gebruik. Kookwater word op die blare gegooi en laat trek, soos 'n tee. Drink drie maal per dag so 'n kelkie vol. Dit is die beste medisyne vir TB. ' $n$ Ou vrou het dit gebruik, as die TB pasiënte huis toe gestuur word, maar hulle is nog nie heeltemal gesond nie. Dit het hulle gehelp om aan te sterk'. [Org (Notobubon pearsonii) is used as medicine for TB. It is used in combination with jantjie-bêrend (Sutherlandia frutescens) and t/nouroeboegoe (Pteronia camphorata). Boiling water is poured on the leaves and allowed to steep, like a tea. Drink a small glassful three times per day. It is the best medicine for TB. An old lady used it when TB patients were sent home before they were fully recovered. It helped them to regain their strength.]

'Dis `n bos. Die wortel maal dit fyn, vir babatjies, stuipe en vir grootmense. Gebruik vir vuil bloed en siek voel, ook vir grootmens stuipe. Die blare word droog en fyn gebruik. Vir siek voel, meng met baarbos en slangbos. Dit word gekook. Baie goed'. [It is a bush. The root, grind it to a powder, for babies, convulsions and for adults. Use for impure blood and when feeling ill, also for adult convulsions. The leaves are used dried and powdered. For 'feeling ill', mix with baarbos (Limeum africanum) and slangbos (Stoebe plumosa). It is boiled (a decoction). Very good.]

't ôrrôboegoe of t' ôrrôbosboegoe - die t’ôrrô verwys na die nek; dit word gebruik veral vir kinders vir ontsteking om en agter in die nek (as dit so rooi word). Dit is ook 'n bors medisyne; hierdie bos is baie goeie medisyne.' [The t' ôrrô refers to the back of the neck; it is used especially for children, to treat inflammation around and behind the neck (when it turns red). It is also a chest medicine; this shrub is very good medicine.]

aambeiebos: Corneels 'Kaldei' Christiaan (Spoegrivier, Namaqualand)

'Hy groei meer in die nat wêreld en word gebruik vir aambeie' [It grows in moist places and is used to treat haemorrhoids.]

t’ôrrôbos or t’ôrrôboegoe: Esau Flink (Vanrhynsdorp)

'-' indicates no information 
Table 3: $\quad$ Compounds of six samples of Pteronia camphorata as identified by GC-MS (percentage area)

\begin{tabular}{|c|c|c|c|c|c|c|c|}
\hline & Locality & & uppert & & & ntagu $\mathrm{F}$ & \\
\hline & Samples & 1 & 2 & 3 & 1 & 2 & 3 \\
\hline & Yield (\% dry weight) & 0.53 & 0.59 & 0.71 & NA & NA & NA \\
\hline RRI & Major compounds & & & & & & \\
\hline 1000 & Decane & 0.3 & 0.5 & 1.9 & - & - & - \\
\hline 1032 & $\alpha$-Pinene & 0.3 & 0.6 & 0.5 & 0.5 & 0.2 & 0.7 \\
\hline 1118 & $\beta$-Pinene & 2.1 & 3.1 & 2.0 & 1.1 & 0.7 & 0.9 \\
\hline 1132 & Sabinene & 3.5 & 3.6 & 5.1 & 9.1 & 7.1 & 12.7 \\
\hline 1174 & Myrcene & 6.0 & 1.6 & 2.5 & - & - & - \\
\hline 1176 & $\alpha$-Phellandrene & - & - & - & 1.6 & 1.7 & 5.5 \\
\hline 1188 & $\alpha$-Terpinene & 0.3 & 0.2 & 0.3 & - & 0.1 & 0.3 \\
\hline 1195 & Dihydro1,8-cineole & - & - & - & - & 0.1 & 0.1 \\
\hline 1203 & Limonene & 9.9 & 17.1 & 2.0 & 5.0 & 3.8 & 7.7 \\
\hline 1213 & 1,8-Cineole & 22.3 & 17.2 & 26.5 & 42.7 & 40.4 & 42.6 \\
\hline 1246 & (Z)- $\beta$-Ocimene & 4.6 & 5.5 & 4.6 & 1.0 & 0.8 & 1.5 \\
\hline 1255 & $\gamma$-Terpinene & 0.8 & 0.4 & 0.6 & 1.2 & 0.4 & 0.7 \\
\hline 1266 & (E)- $\beta$-Ocimene & 2.6 & 2.7 & 2.3 & 0.2 & 0.03 & 0.1 \\
\hline 1280 & $p$-Cymene & 3.5 & 15.7 & 25.6 & 17.1 & 21.1 & 10.0 \\
\hline 1290 & Terpinolene & - & - & - & 0.3 & - & 0.1 \\
\hline 1400 & Tetradecane & 0.9 & 5.4 & 4.1 & - & - & - \\
\hline 1450 & trans-Linalool oxide (furanoid) & - & - & - & - & - & 0.1 \\
\hline 1474 & trans-Sabinene hydrate & - & - & - & 0.4 & 0.8 & 0.6 \\
\hline $1450+$ & cis-Linalool oxide (furanoid) & - & - & - & - & 0.1 & 0.1 \\
\hline 1500 & Pentadecane & - & 5.7 & 4.2 & - & - & - \\
\hline 1512 & Dillether & - & - & - & - & 0.04 & - \\
\hline 1553 & Linalool & - & - & - & 0.4 & 2.8 & 3.1 \\
\hline 1571 & trans-p-Menth-2-en-1-ol & - & - & - & 0.3 & 0.1 & 0.2 \\
\hline 1586 & Pinocarvone & - & - & - & 0.1 & - & - \\
\hline 1600 & Hexadecane & 1.0 & 5.4 & 4.2 & - & - & - \\
\hline 1611 & Terpinen-4-ol & 5.3 & 2.3 & 3.6 & 5.8 & 3.1 & 2.4 \\
\hline 1629 & cis- $\alpha$-Bisabolene & 0.2 & 0.3 & - & - & - & - \\
\hline 1632 & cis- $p$-Menth-2-en-1-ol & - & - & - & - & - & 0.2 \\
\hline 1639 & trans-p-Menth-2,8-dien-1-ol & - & - & - & 0.4 & 0.4 & - \\
\hline 1648 & Myrtenal & - & - & - & 0.1 & 0.2 & 0.1 \\
\hline 1651 & Sabinaketone & - & - & - & 0.3 & 0.2 & 0.2 \\
\hline 1661 & trans-Pinocarveol & - & - & - & 0.2 & 0.2 & 0.1 \\
\hline 1662 & Estragol & 1.0 & 0.7 & 0.4 & - & - & - \\
\hline 1671 & Methyl chavicol (estragol) & - & - & - & 4.5 & 6.8 & 2.9 \\
\hline 1682 & $\alpha$-Terpineol & - & - & - & 2.3 & 4.8 & 3.9 \\
\hline 1700 & Limonene-4-ol & - & - & - & 0.05 & 0.4 & - \\
\hline 1700 & Heptadecane & 1.0 & 4.3 & 3.4 & - & - & - \\
\hline 1751 & Carvone & 0.2 & 0.7 & - & 1.2 & 1 & 0.7 \\
\hline 1755 & Bicyclogermacrene & 1.0 & 0.6 & 0.4 & - & - & - \\
\hline 1765 & Geranyl acetone & - & - & - & - & 0.1 & 0.1 \\
\hline 1773 & $\delta$-Cadinene & - & - & - & 0.1 & - & 0.1 \\
\hline 1776 & $\gamma$-Cadinene & - & - & - & - & 0.1 & - \\
\hline
\end{tabular}




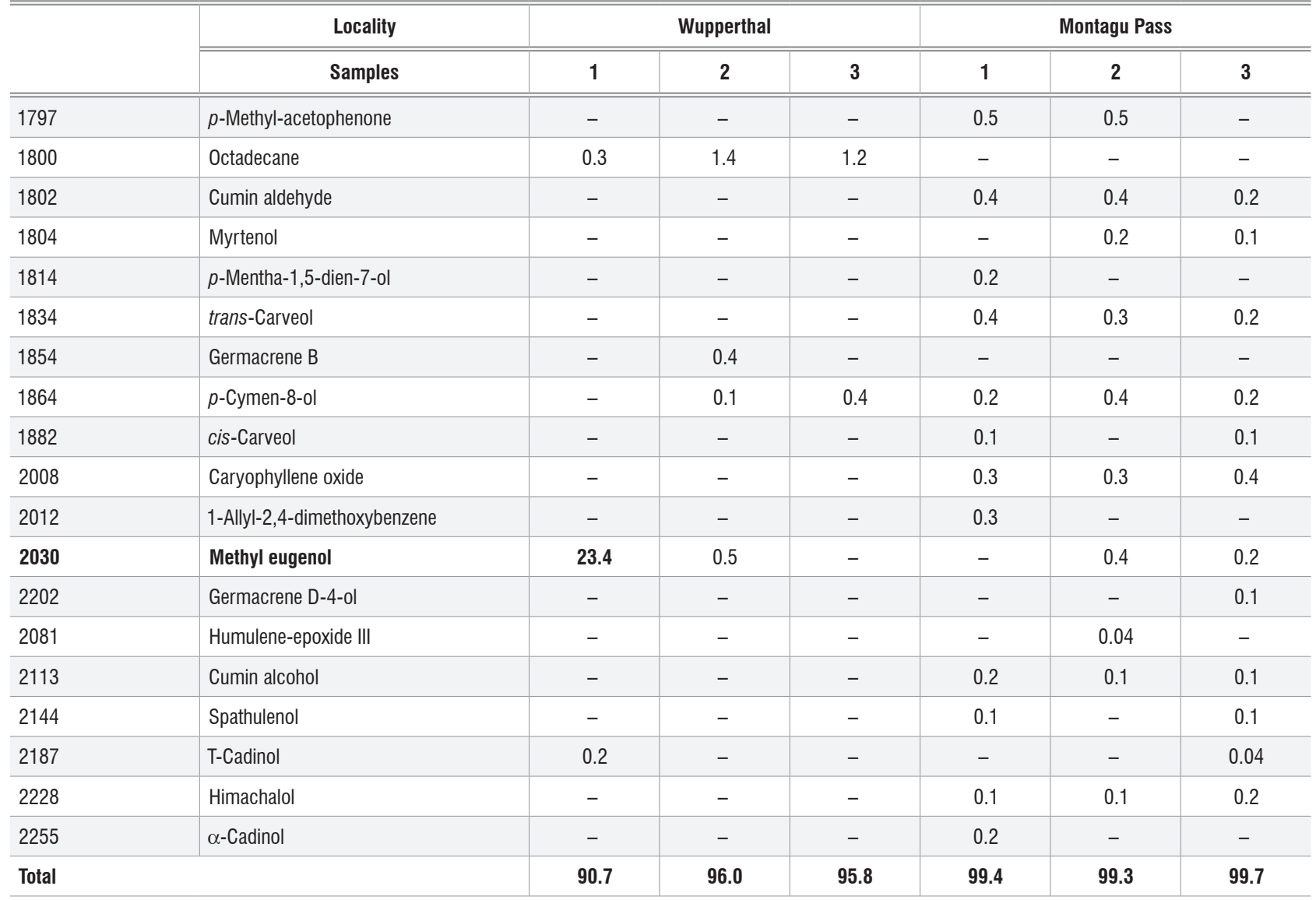

Note: Three essential oil samples of $P$. camphorata from Kleinvlei, Wupperthal (P. camphorata var. armata) are compared with published results for three samples of $P$. camphorata var. camphorata from Montagu Pass. ${ }^{16}$ The three specimens from each population are shown as 1, 2 and 3.

Table 4: $\quad$ Minimum inhibitory concentrations for extracts and essential oils of three specimens of Pteronia camphorata var. armata

\begin{tabular}{|c|c|c|c|c|c|}
\hline \multirow[b]{2}{*}{ Extract } & \multirow[b]{2}{*}{ Sample number } & \multicolumn{4}{|c|}{ Minimum inhibitory concentration (mg/ml) } \\
\hline & & $\begin{array}{l}\text { Moraxella catarrhalis } \\
\text { ATCC } 23246\end{array}$ & $\begin{array}{c}\text { Mycobac-terium } \\
\text { smegmatis ATCC } 14468\end{array}$ & $\begin{array}{c}\text { Crypto-coccus } \\
\text { neoformans ATCC } 90112\end{array}$ & $\begin{array}{c}\text { Klebsiella pneumoniae } \\
\text { ATCC } 13883\end{array}$ \\
\hline $\mathrm{H}_{2} \mathrm{O}$ extract & 1 & $>8$ & 3.0 & 0.5 & 8.0 \\
\hline $\mathrm{H}_{2} \mathrm{O}$ extract & 2 & $>8$ & 2.0 & $>8$ & 8.0 \\
\hline $\mathrm{H}_{2} \mathrm{O}$ extract & 3 & $>8$ & 1.5 & $>8$ & 8.0 \\
\hline $\mathrm{MeOH}: \mathrm{H}_{2} \mathrm{O}$ extract & 1 & $>8$ & 8.0 & 0.2 & $>8$ \\
\hline $\mathrm{MeOH}: \mathrm{H}_{2} \mathrm{O}$ extract & 2 & $>8$ & 8.0 & 0.1 & $>8$ \\
\hline $\mathrm{MeOH}: \mathrm{H}_{2} \mathrm{O}$ extract & 3 & $>8$ & 1.5 & 0.1 & $>8$ \\
\hline $\mathrm{MeOH}: \mathrm{CH}_{2} \mathrm{Cl}_{2}$ extract & 1 & 4.0 & 0.5 & 0.8 & 4.0 \\
\hline $\mathrm{MeOH}: \mathrm{CH}_{2} \mathrm{Cl}_{2}$ extract & 2 & $>8$ & 0.3 & 0.8 & 4.0 \\
\hline $\mathrm{MeOH}: \mathrm{CH}_{2} \mathrm{Cl}_{2}$ extract & 3 & $>8$ & 0.5 & 0.8 & 1.5 \\
\hline Essential oil & 1 & $>16$ & 1.0 & 0.3 & 4.0 \\
\hline Essential oil & 2 & $>16$ & 1.0 & 0.3 & 4.0 \\
\hline Essential oil & 3 & $>16$ & 1.0 & 0.5 & 4.0 \\
\hline \multicolumn{2}{|c|}{ Positive control (ciprofloxacin/amphotericin B) } & $0.313 \mu \mathrm{g}$ & $0.313 \mu \mathrm{g}$ & $2.5 \mu \mathrm{g}$ & $0.078 \mu \mathrm{g}$ \\
\hline
\end{tabular}

Note: Concentrations were tested on a selection of pathogens associated with respiratory infections, including a yeast (Cryptococcus neoformans), two Gram-negative bacteria (Moraxella catarrhalis and Klebsiella pneumoniae) and one Gram-positive bacterium (Mycobacterium smegmatis). 
This word appears to be derived from a corruption of the word 'Inhora' (I denoting the dental click) and boegoe (the common Khoisan term for aromatic bushes). It was explained to B.E.V.W. that the term |nhora in the San culture refers to the 'life force' in human beings, which is believed to be situated in the nape of the neck. Directly translated the name means 'life force buchu', reflecting the perceived importance of this plant species.

Recent enquiries in various parts of the Western and Northern Cape provinces (including the Cederberg region, where the species is quite common) revealed only a few known contemporary uses. In the Kamiesberg area of Namaqualand in Northern Cape, we located two herbalists with original knowledge about the species and its uses in the Nama culture. The late Anna 'Boom' Stewe was a herbalist from Leliefontein in the Kamiesberg, who obtained her medicinal knowledge from the late Jan 'Bordhoed' Beukes, a local bossiedokter - a term of honour for an acknowledged herb doctor. The plant, which Anna Stewe called |nôrraboegoe, is used in a mixture with org [Notobubon pearsonii (Adamson) Magee] and jantije-bêrend [Sutherlandia frutescens (L.) R. $\mathrm{Br}$. which is] [=Lessertia frutescens (L.) Goldblatt \& J.C. Manning] to treat tuberculosis. A small glass (kelkie) of a hot water infusion (tea) of the leaves of the three species is taken three times a day, and is considered to be the best medicine for tuberculosis. This medicine was used by an elderly lady, whose name is no longer recalled, for convalescent tuberculosis patients. Powdered leaves mixed with other herbs can also be used medicinally as snuff, and infusions of a leafy twig in hot milk or water are used to alleviate toothache. Powdered leaves are applied to a piece of cotton wool and inserted into the ear for relief of earache (dit het 'n pyndodende effek - 'it has a painkilling effect'). The mixture can also be used for flatulence ('to remove wind'). The use against earache and flatulence was confirmed by three other local inhabitants of Kamiesberg, and another person added that an infusion can be used to treat rheumatism. ${ }^{8}$

The second local expert in the Kamiesberg was the late Gert 'Joelk' Dirkse, a herbal doctor from Paulshoek and one of the last professional bossiedokters in Namaqualand. He independently supplied information about $P$. camphorata. Powdered root is used to treat febrile convulsions in infants, and powdered leaves are used to treat convulsions and epilepsy in adults as well as for blood purification. Gert Dirkse stated that a decoction of the leaves, mixed with baarbos (Limeum africanum $\mathrm{L}$.) and slangbos [Stoebe plumosa (L.) Thunb.] is taken orally and is very effective in treating general malaise (siek voel).

We also heard recent anecdotes from the small Namaqualand village of Spoegrivier. An experienced and highly knowledgeable midwife, Ouma Sarah 'Toesie' Fortuin, still remembered |ôrrôboegoe or |ôrrôbosboegoe. According to Sarah Fortuin, |ôrrô refers to the back of the neck, and the plant is used to treat inflammation and redness of the neck in children. It is also a medicine for chest ailments, and is considered highly effective (hierdie bos is baie goeie medisyne - 'this shrub is very good medicine'). Corneels 'Kaldei' Christiaan from the same village reported that the plant grows only in moist areas and is used for the treatment of haemorrhoids - hence his vernacular name for the plant, aambeiebos (haemorrhoids bush). Further south, near Vanrhynsdorp not far from Nieuwoudtville, Esau Flink reported that he uses a decoction of the leaves and twigs to treat influenza. He referred to it as t' ôrrôbos.

Given its obvious medicinal importance, it is surprising that the uses of $P$. camphorata have remained almost unknown to science until recently. We were fortunate to have the opportunity to record, and preserve for posterity, the rich knowledge of two very knowledgeable and experienced herbalists, Anna Stewe and Gert Dirkse. Sadly, neither of them had any apprentices to whom they could pass on their knowledge.

\section{Anatomy}

The leaves of $P$. camphorata are amphistomatic. They have a thin cuticle and the outer periclinal cell walls of the epidermal cells are markedly thickened. The mesophyll is composed of usually two layers of palisade parenchyma, more highly developed adaxially than abaxially, which surround the central spongy parenchyma (Figure 2). Secretory structures that can be referred to as oil glands or cavities occur in the spongy parenchyma adjacent to the phloem of some vascular bundles. Macroscopically they are visible as translucent dots (Figure 1). Secretory trichomes are situated in the medial adaxial groove, but can sometimes also be found in the corresponding position on the abaxial surface.

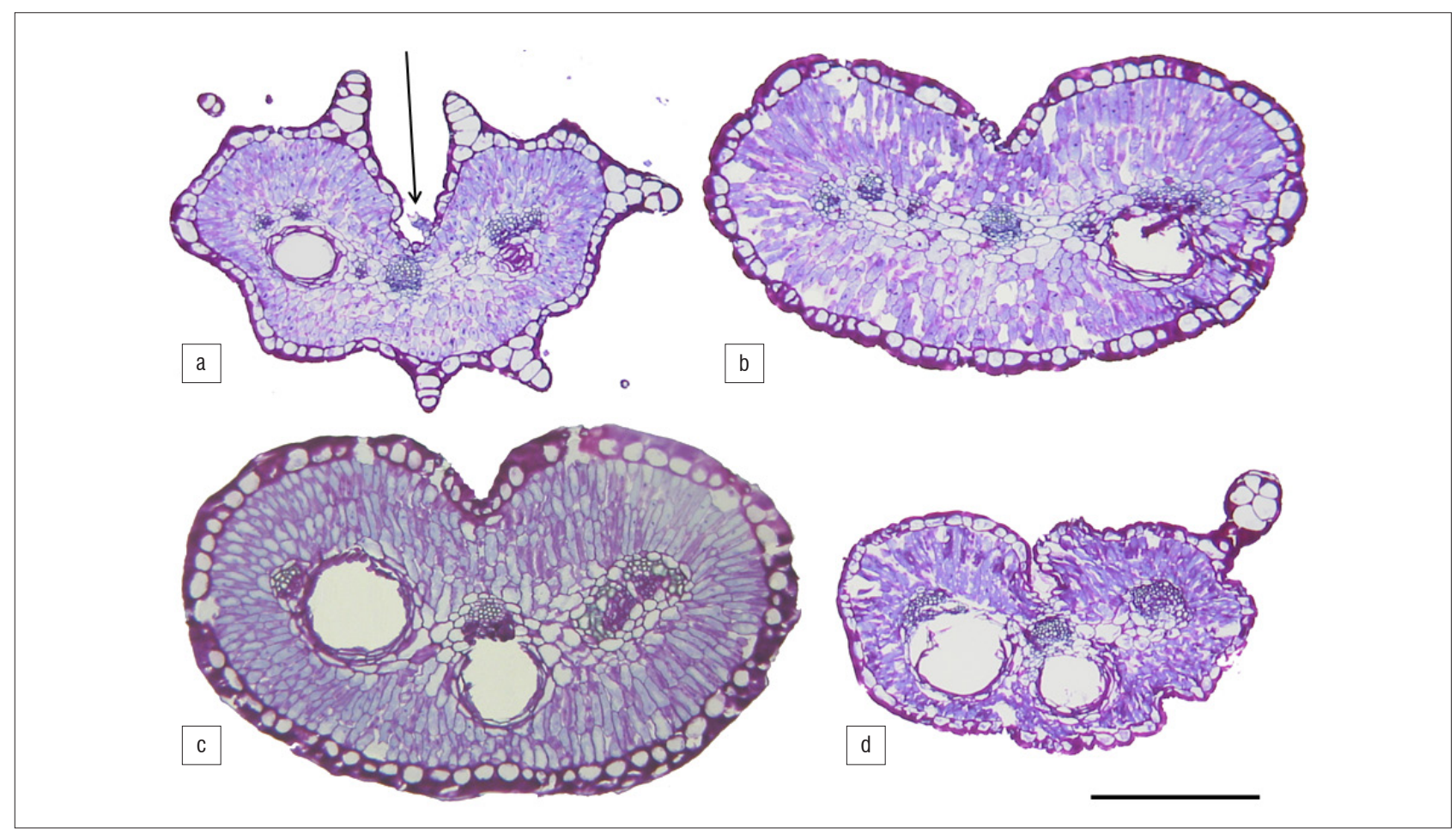

Figure 2: Transverse sections of leaves from four varieties of Pteronia camphorata. (a) P. camphorata var. armata, (b) P. camphorata var. camphorata, (c) P. camphorata var. laevigata, and (d) P. camphorata var. Iongifolia. Oil glands are present in all, and secretory trichomes in (a) and (d).

Key: The arrow indicates a secretory trichome; scale bar $=0.4 \mathrm{~mm}$. 
It appears that three types of secretory structures are present in the genus Pteronia, and the ethnobotanically relevant species can be classified into four groups based on their combinations. The structures are as follows: (1) globose oil glands or cavities, similar to those in Citrus, which are present in P. onobromoides D.C., P. stricta Aiton and $P$. succulent Thunb.; (2) oil ducts associated with the vascular bundles, mainly the midrib, which are present in P. adenocarpa Harv.; (3) oil ducts associated with the vascular bundles as well as secretory trichomes, which occur in $P$. cinerea L.f., $P$. divaricata Less., $P$. incana D.C. and $P$. lucillioides D.C.; and (4) globose oil glands and secretory trichomes mainly in the medial grooves - this type is present in $P$. camphorata. The leaf anatomy of Pteronia species appears to be of considerable value in providing diagnostic characters, and has the potential to contribute to a better understanding of the infrageneric taxonomy and relationships of the genus.

\section{Essential oil composition}

We identified 21 to 25 volatile components in the three samples of P. camphorata var. armata that we analysed from Wupperthal (Table 3). A similar combination of main compounds was found in $P$. camphorata var. camphorata from Montagu Pass in the southern Cape, as studied by Coovadia ${ }^{16}$ and reported by Viljoen et al. ${ }^{17}$ The major compounds in one or both of the varieties are several monoterpenes as well as sesquiterpenes (Table 3). The two varieties agree in the presence of sabinene, limonene, 1,8-cineole, $p$-cymene and terpinene-4-ol as main compounds. In addition, (Z)- $\beta$-ocimene is a major constituent in Wupperthal samples but a minor constituent in Montagu Pass samples. Estragol occurs at relatively high levels at Montagu but only as minor compounds at Wupperthal. Methyl eugenol was a major compound in one of the Wupperthal samples. Both varieties have smaller amounts of $\alpha$-pinene, $\beta$-pinene, $\gamma$-terpinene and $(E)-\beta$-ocimene.

A number of non-volatile diterpenes and other phenolic compounds have been isolated from $P$. camphorata and other Pteronia species. ${ }^{18}$ These include 3,4-dimethoxypropiophenone, eugenol methyl ether and several other more widespread compounds. The biological, chemotaxonomic and medicinal significance of these compounds are as yet unknown.

We compared the main essential oil compounds in $P$. camphorata with those of four other ethnobotanically relevant species for which data are available. ${ }^{16}$ The results showed the following general patterns: (1) sabinene, limonene, 1,8-cineole, $p$-cymene and myrcene are main constituents in most of the species, and the same pattern is evident for $P$. camphorata; (2) $\beta$-pinene is a major compound in $P$. adenocarpa and $P$. incana and is present as a minor compound in all other species; and (3) sesquiterpenoids appear to be more restricted in their distribution. There might well be a link between the essential oil composition and antimicrobial activity. A previous study showed that cineole and limonene may interact synergistically to exert enhanced antimicrobial activity. ${ }^{19}$

\section{Antimicrobial activity}

The results of our antimicrobial study on the extracts of $P$. camphorata are shown in Table 4, with noteworthy activity highlighted in bold text. Noteworthy activities for extracts were considered where MIC values were below $1.0 \mathrm{mg} / \mathrm{ml}^{20-21}$ and for essential oil samples where MIC values were below $2.0 \mathrm{mg} / \mathrm{ml}^{22}$. The methanol-to-dichloromethane $\left(\mathrm{MeOH}: \mathrm{CH}_{2} \mathrm{Cl}_{2}\right.$ ) extracts were the most active against Mycobacterium smegmatis, with MIC values as low as $0.3 \mathrm{mg} / \mathrm{ml}$ to $0.5 \mathrm{mg} / \mathrm{ml}$. The methanol-to-water $\left(\mathrm{MeOH}: \mathrm{H}_{2} \mathrm{O}\right)$ extracts were the most active against C. neoformans, with MIC values as low as $0.1 \mathrm{mg} / \mathrm{ml}$ to $0.2 \mathrm{mg} / \mathrm{ml}$. The essential oils also showed strongest antimicrobial activity against C. neoformans, with the most noteworthy having an MIC value of $0.3 \mathrm{mg} / \mathrm{ml}$.

Water and methanol-to-water extracts generally showed poor to no activity at the highest concentration tested, against all organisms studied except for $C$. neoformans. In the latter case, the mean MIC value was $0.5\left(\mathrm{H}_{2} \mathrm{O}\right.$ extract), with MIC values ranging from $1.5 \mathrm{mg} / \mathrm{ml}$ to $3.0 \mathrm{mg} / \mathrm{ml}$ $\left(\mathrm{H}_{2} \mathrm{O}\right.$ extracts) for the various Mycobacterium species tested.

\section{Conclusion}

P. camphorata is poorly known as a medicinal plant, but available information and recently recorded ethnobotanical data suggest it was once an important Khoisan remedy. Almost no local knowledge or local users could be found in most of the rural localities where the plants grow. The traditional uses include treatment of respiratory conditions (colds, fever, influenza, chest ailments and tuberculosis) and inflammation of the neck, convulsions and haemorrhoids. These uses suggest the plant has antimicrobial, anti-inflammatory and antipyretic properties.

The globose oil glands found in $P$. camphorata are similar to those of $P$. onobromoides, $P$. stricta and $P$. succulenta but not those of any other species. $P$. camphorata differs from the others by the presence of additional glandular trichomes in the medial grooves. The leaf anatomy appears to have some diagnostic value at the species level, and holds considerable potential as a source of taxonomic characters.

$P$. camphorata essential oil has a similar combination of main compounds as that found in other Pteronia species: sabinene, limonene, 1,8-cineole, $p$-cymene and terpinene-4-ol are the main constituents. Smaller amounts of $\alpha$-pinene, $\beta$-pinene, (Z)- $\beta$-ocimene, $\gamma$-terpinene, $(E)$ - $\beta$-ocimene and myrcene also occur in all or most of the samples of this species. The plant has small amounts of sesquiterpenes, such as bicyclogermacrene - which is a main compound in $P$. divaricata and a minor compound in P. incana.

Most of the extracts, as well as the essential oil of the plant, display activity against $C$. neoformans. The dichloromethane extracts and essential oil samples were active against $M$. smegmatis. The level of activity against these respiratory pathogens seems to support the reported efficacy of the traditional treatment against tuberculosis, colds and influenza.

\section{Authors' contributions}

I.M.H. prepared the samples and performed the experiments; P.M.T. provided anatomical know-how and infrastructure, and prepared the anatomical descriptions; S.F.V.V. was responsible for the experimental design of antimicrobial tests, and provided the microbial samples and infrastructure; G.P.P.K. performed the GC-MS analyses and calculations; J.M.N. contributed original ethnobotanical data; A.M.V. made conceptual contributions, guided the essential oil analyses and provided the analytical infrastructure; and B.E.V.W. was the project leader, conceptualised the study, wrote the first draft and contributed taxonomic and ethnobotanical data.

\section{Acknowledgements}

Financial support from the National Research Foundation is gratefully acknowledged. We thank and honour Mr Willem 'Blikkies' Steenkamp of the farm Oorlogskloof near Nieuwoudtville; the late Ms Anna 'Boom' Stewe of Leliefontein; the late Mr Gert 'Joelk' Dirkse of Paulshoek; Mrs Sarah 'Toesie' Fortuin and Corneels 'Kaldei' Christiaan of Spoegrivier; and Mr Esau Flink of Vanrhynsdorp, for sharing their remarkable traditional knowledge on medicinal plants. We also thank Mr Paul Herman at the South African National Biodiversity Institute in Pretoria for kindly identifying the four varieties of $P$. camphorata used in this study.

\section{References}

1. Laidler PW. The magic medicine of the Hottentots. S Afr J Sci. 1928;25:433447.

2. Nortje JM, Van Wyk B-E. Medicinal ethnobotany of the Kamiesberg, Namaqualand, South Africa. J Ethnopharmacol. 2015;171:205-222. http:// dx.doi.org/10.1016/j.jep.2015.04.049

3. Hutchinson J, Phillips EP. A revision of the genus Pteronia (Compositae). Ann S Afr Mus. 1917;9:277-329.

4. Hulley IM, Viljoen AM, Tilney PM, Van Vuuren SF, Kamatou GPP, Van Wyk B-E Ethnobotany, leaf anatomy, essential oil composition and antibacterial activity of Pteronia onobromoides (Asteraceae). S Afr J Bot. 2010;76:43-48. http:// dx.doi.org/10.1016/j.sajb.2009.06.012 
5. Hulley IM, Viljoen AM, Tilney PM, Van Vuuren SF, Kamatou GPP, Van Wyk B-E. The ethnobotany, leaf anatomy, essential oil variation and biological activity of Pteronia incana (Asteraceae). S Afr J Bot. 2010;76:668-675. http://dx.doi. org/10.1016/j.sajb.2010.08.007

6. Hulley IM, Viljoen AM, Tilney PM, Van Vuuren SF, Kamatou GPP, Van Wyk B-E. Pteronia divaricata (Asteraceae): A newly recorded Cape herbal medicine. S Afr J Bot. 2011;77:66-74. http://dx.doi.org/10.1016/j.sajb.2010.05.010

7. International Society of Ethnobiology. International Society of Ethnobiology Code of Ethics. Bristol, Vermont; 2006 (with 2008 additions). [Cited 2015 May 6]. Available from: http://ethnobiology.net/code-of-ethics/

8. Nortje JM. Medicinal ethnobotany of the Kamiesberg, Namaqualand, Northern Cape Province, South Africa [MSc dissertation]. Johannesburg: University of Johannesburg; 2011

9. Marloth R. The Flora of South Africa. Volume 3. Cape Town: Darter Bros; 1932. p. 250

10. Smith CA. Common names of South African plants. Memoirs of the Botanical Survey of South Africa 35. Pretoria: Department of Agricultural Technical Services; 1966.

11. Burman L, Bean A. Hottentots Holland to Hermanus. Botanical Society of South Africa: Kirstenbosch; 1985.

12. Watt JM, Breyer-Brandwijk MG. The medicinal and poisonous plants of southern and eastern Africa. 2nd ed. London: Livingstone; 1962. p. 255.

13. Kling H. Die sieketrooster: ' $n$ Noodanker in tyd van siekte en ongevalle. Cape Town: Van de Sandt de Villiers; 1923
14. Arnold TH, Prentice CA, Hawker LC, Snyman EE, Tomalin M, Crouch NR, et al. Medicinal and magical plants of southern Africa: An annotated checklist. Strelitzia, Volume 13. Pretoria: National Botanical Institute; 2002. p. 37.

15. Van Wyk B-E, Gericke N. People's plants: A guide to useful plants of Southern Africa. Pretoria: Briza Publications; 2000. p. 218, p. 224.

16. Coovadia ZH. The antimicrobial properties and chemical composition of leaf extracts and essential oils of indigenous Pteronia species [MSc dissertation]. Johannesburg: University of the Witwatersrand; 2007.

17. Viljoen AM, Kamatou GPP, Coovadia ZH, Özek T, Başer KHC. Rare sesquiterpenes from South African Pteronia species. S Afr J Bot. 2010;76: 146-152. http://dx.doi.org/10.1016/j.sajb.2009.07.012

18. Zdero C, Jakupovic J, Bohlmann F. Diterpenes and other constituents from Pteronia species. Phytochemistry. 1990;29:1231-1245. http://dx.doi. org/10.1016/0031-9422(90)85434-H

19. Van Vuuren SF, Viljoen AM. Antimicrobial activity of limonene enantiomers and 1,8-cineole alone and in combination. Flavour Fragr J. 2007:22:540-544. http://dx.doi.org/10.1002/ffj.1843

20. Gibbons S. Anti-staphylococcal plant natural products. Nat Prod Rep. 2004; 21:263-277. http://dx.doi.org/10.1039/b212695h

21. Rios JL, Recio MC. Medicinal plants and antimicrobial activity. J Ethnopharmacol. 2005;100:80-84. http://dx.doi.org/10.1016/.j.jep.2005.04.025

22. Van Vuuren SF. Antimicrobial activity of South African medicinal plants. J Ethnopharmacol. 2008;119:462-472. http://dx.doi.org/10.1016/i.jep.2008.05.038 